\title{
Pembuatan Aplikasi Diagnosa Kerusakan Mesin Sepeda Motor Matic dengan Case-Based Reasoning
}

\author{
Sandy Kosasi \\ Program Studi Sistem Informasi STMIK Pontianak \\ E-mail: sandykosasi@yahoo.co.id
}

\begin{abstract}
Abstrak
Sepeda motor matic sebagai terobosan baru kendaraan roda dua dengan transmisi otomatis memberikan implikasi kepada sistem perawatannya. Jumlah mekanik yang terbatas dan minimnya pengetahuan pengguna menyebabkan berbagai kesulitan dalam perawatannya khususnya dalam mengatasi kerusakan mesin. Pembuatan aplikasi sistem cerdas melalui metode case-based reasoning dapat memberikan kemudahan melakukan diagnosis awal secara mandiri. Case-based reasoning memiliki kemampuan dapat memberikan hasil diagnosis yang lebih akurat berdasarkan kejadian terdahulu dan dapat direvisi kembali dalam memecahkan permasalahan terbaru. Metode perancangan aplikasinya menggunakan reuse-based yang meliputi enam tahap yaitu spesifikasi persyaratan, analisis komponen, modifikasi persyaratan, integrasi design sistem dengan reuse, pengembangan dan integrasi, serta validasi sistem. Tujuan penelitian untuk melakukan diagnosa kerusakan mesin sepeda motor matic dan memberikan solusi awal mengenai kondisi kerusakan dan pencegahannya melalui media situs web. Hasil pengujian memperlihatkan aplikasi ini memiliki kemampuan mendiagnosa kerusakan dan memberikan solusi penyelesaian masalah dari pengguna dengan rata-rata nilai similaritas antara 0,62 dan 0,7 dengan nilai keakuratan solusi dari pakar sebesar $80 \%$ dan $90 \%$.
\end{abstract}

Kata Kunci - Case-Based Reasoning, Kerusakan Sepeda Motor Matic, Similaritas

\begin{abstract}
Automatic motorcycles as a new breakthrough of two-wheeled vehicle with an automatic transmission have implications for the system maintenance. A limited number of mechanics and lack of users' knowledge cause many difficulties in treatment, especially in dealing with the engine damage. The Design of the intelligent system through case-based reasoning method can provide easiness of initial diagnosis independently. Case-based reasoning has the ability to provide more accurate diagnosis results based on the previous events and may be revised to solve the latest problems. The design of application uses a reuse-based method that includes six stages: requirements specification, component analysis, modification of the terms, integration with reuse system design, development and integration, and system validation. The purpose of the research is for diagnosing automatic motorcycle engine damage and provide an initial solution on its condition and prevention through the medium of the website. The test results demonstrate that this application has the ability to diagnose the damage and provide problem solving solutions to the users with an average of similarity value between 0,62 and 0,7 with an accuracy value of expert solutions for $80 \%$ and $90 \%$.
\end{abstract}

Keywords - Case-Based Reasoning, Automatic motorcycle engine damage, Similarity. 


\section{PENDAHULUAN}

Minat masyarakat yang semakin meningkat menggunakan sepeda motor matic memberikan banyak keluwesan bagi pengendaranya. Selain sistem transmisinya otomatis, mudah melakukan manuver untuk jalan-jalan yang padat, sempit dan tidak merata, serta memiliki performa mesin dengan tenaga dan kecepatan yang handal. Namun sebagian besar pengguna sepeda motor matic sering mengalami kesulitan melakukan perawatan dan diagnosis kerusakan karena terbatasnya pengetahuan. Kenyataannya sebagian besar jasa servis/perawatan tidak memiliki mekanik yang handal sehingga tidak dapat melakukan diagnosis kerusakan secara tepat dan hanya berdasarkan kepada perkiraan saja. Kecenderungannya masih banyak mekanik yang hanya mengandalkan kepada intuisinya saja sehingga hasil perawatan menjadi tidak maksimal dan menimbulkan kekecewaan bagi konsumen. Tingkat kesulitan ini membutuhkan pemanfaatan teknologi informasi melalui metode yang menggabungkan keahlian dan pengetahuan seorang pakar untuk membangun sebuah aplikasi pengetahuan baru berdasarkan sejumlah kasus yang sudah terjadi dan dikenal dengan istilah Case-Based Reasoning [1].

Metode Case-Based Reasoning melakukan proses penyelesaian masalah dengan memanfaatkan pengalaman sebelumnya. Case-Based Reasoning merupakan salah satu metode pemecahan masalah yang dalam mencari solusi dari suatu kasus yang baru, sistem akan melakukan pencarian terhadap solusi dari kasus lama yang memiliki permasalahan yang sama [1]. Metode Case-Based Reasoning memiliki kelebihan dibandingkan dengan sistem berbasis aturan (rule base system) dalam hal akuisisi pengetahuan terletak pada kumpulan pengalaman/kasuskasus sebelumnya. Metode ini tetap dapat melakukan penalaran walaupun terdapat data yang tidak lengkap. Ketika proses retrieval dilakukan, ada kemungkinan antara kasus baru dengan kasus lama pada basis kasus tidak mirip. Namun, dari ukuran similarity tersebut tetap dapat dilakukan penalaran dan melakukan evaluasi terhadap ketidaklengkapan atau ketidaktepatan data yang diberikan [2]. Perancangan Case-Based Reasoning ini bisa digunakan untuk membantu pakar dalam mengidentifikasi penyakit dan memberi cara penanggulangannya. Hal ini tidak berarti menggantikan kedudukan pakar, tetapi hanya membantu dalam mengkonfirmasikan keputusannya, karena mungkin bisa terdapat banyak alternatif yang harus dipilih secara tepat [3].

Sudah banyak penelitian yang menggunakan metode Case-Based Reasoning dengan tujuan membantu memberikan berbagai kemudahan dalam kehidupan manusia. Kebanyakan hasil penelitian lebih banyak menyoroti dari sisi diagnosis penyakitnya saja, beberapa diantaranya adalah untuk mengidentifikasi penyakit manusia, mendiagnosa penyakit akibat virus eksantema, kebutuhan deteksi dini penyakit leukemia, penyakit diare pada manusia, dan diagnosa awal untuk penyakit ginjal [4-8]. Perbedaannya ada pada perhitungan similaritinya, diantaranya menggunakan probabilitas bayes, metode indexing dan nearest neighbor, K-nearest neighbor, dan ada juga yang menggunakan metode sorenson coefficient [9]. Merujuk kepada penelitian sebelumnya, dalam penelitian ini menggunakan pendekatan reuse-based dan perhitungan similaritinya menggunakan faktor pembobotan nilai tertinggi. Sementara tujuan penelitiannya adalah untuk memberikan kemudahan kepada masyarakat mengenai informasi pemeliharan/perawatan dan diagnosis awal jenis kerusakan sepeda motor matic melalui media situs web. Melalui aplikasi diagnosis ini dapat menjadi solusi awal bagi pengguna sepeda motor matic. Tidak hanya sebatas kalau sudah terjadi kerusakan, tetapi dapat juga sebagai cara preventif memahami lebih mendalam cara perawatan yang sepeda motor matic secara baik dan benar. Manfaat bagi pengguna adalah bahwa mereka tidak lagi akan mengalami kesulitan dalam memahami semua gejala dan tingkat kerusakan yang kemungkinan dapat terjadi. Menghindari hal-hal yang tidak diinginkan seperti pihak jasa servis cenderung akan selalu melakukan penggantian sparepart yang sebenarnya tidak perlu. 


\section{METODE PENELITIAN}

Penelitian ini menggunakan bentuk studi literatur dengan metode eksperimen dan melalui proses pengujian similaritas. Untuk metode perancangan aplikasinya menggunakan reuse-based yang meliputi enam tahap yaitu spesifikasi persyaratan, analisis komponen, modifikasi persyaratan, integrasi design sistem dengan reuse, pengembangan dan integrasi, serta validasi sistem. Pendekatan yang berorientasi pemakaian ulang ini bergantung pada sejumlah besar komponen perangkat lunak yang dapat dipakai ulang, yang bisa didapat, dan beberapa kerangka kerja integrasi untuk komponen-komponen ini (Gambar 1) [10].

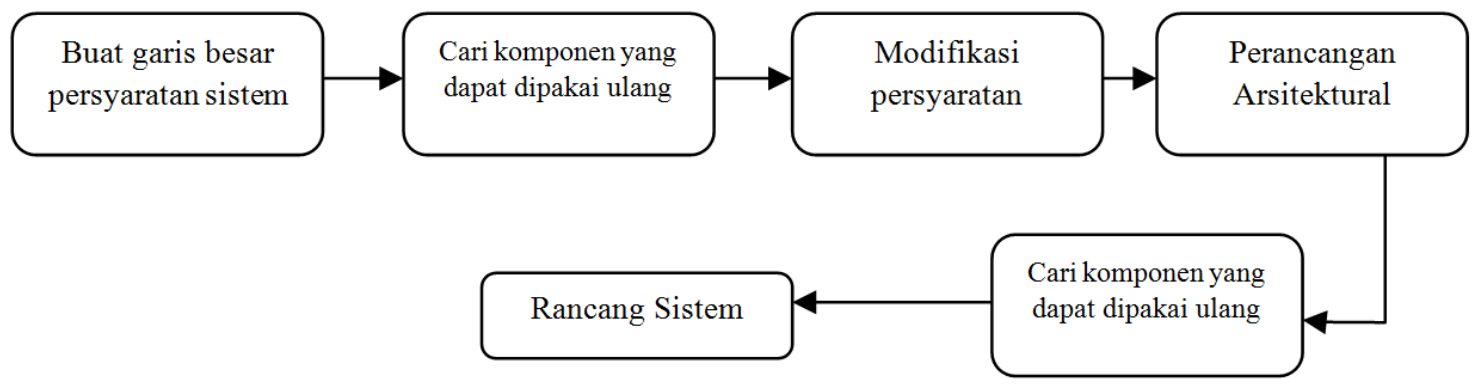

Gambar 1. Metode Pengembangan Reuse-Based

Tahapan case-based reasoning meliputi case retrieve (penelusuran) dimulai dengan tahapan mengenali masalah dan berakhir ketika kasus yang ingin dicari solusinya telah ditemukan serupa dengan kasus yang telah ada. Beberapa tahapan yang terdapat dalam retrieve adalah: (1) identifikasi masalah, (2) memulai pencocokan, dan (3) menyeleksi. Selanjutnya masuk ke proses reuse. Di dalam proses ini, sistem akan menggunakan informasi permasalahan sebelumnya yang memiliki kesamaan untuk menyelesaikan permasalahan yang baru. Tahap berikutnya proses revise, dimana informasi tersebut akan dikalkulasi, dievaluasi, dan diperbaiki kembali untuk mengatasi kesalahan-kesalahan yang terjadi pada permasalahan baru. Terakhir, sistem melakukan proses retain. Proses ini akan mengindeks, mengintegrasi, dan mengekstrak solusi yang baru yang akan disimpan ke dalam knowledge-base untuk menyelesaikan permasalahan yang akan datang dan tentunya yang memiliki unsur-unsur kesamaan.

Tahapan paling penting adalah menentukan tingkat similariti (similarity) antar kasus. Melalui perhitungan similariti antar kasus, maka dapat dibuat daftar terurut dari kasus-kasus yang mirip (similar case). Case Reuse merupakan suatu kasus dalam konteks kasus baru dan terfokus pada dua aspek, yaitu Perbedaan antara kasus yang ada dengan kasus yang baru. Terdapat 2 (dua) cara yang bisa digunakan untuk meng-reuse kasus yang telah ada, yaitu menggunakan ulang solusi dari kasus yang telah ada (transformatial reuse) dan menggunakan ulang metode kasus yang ada untuk membuat solusi (derivational reuse) (Gambar 2) [11]. 


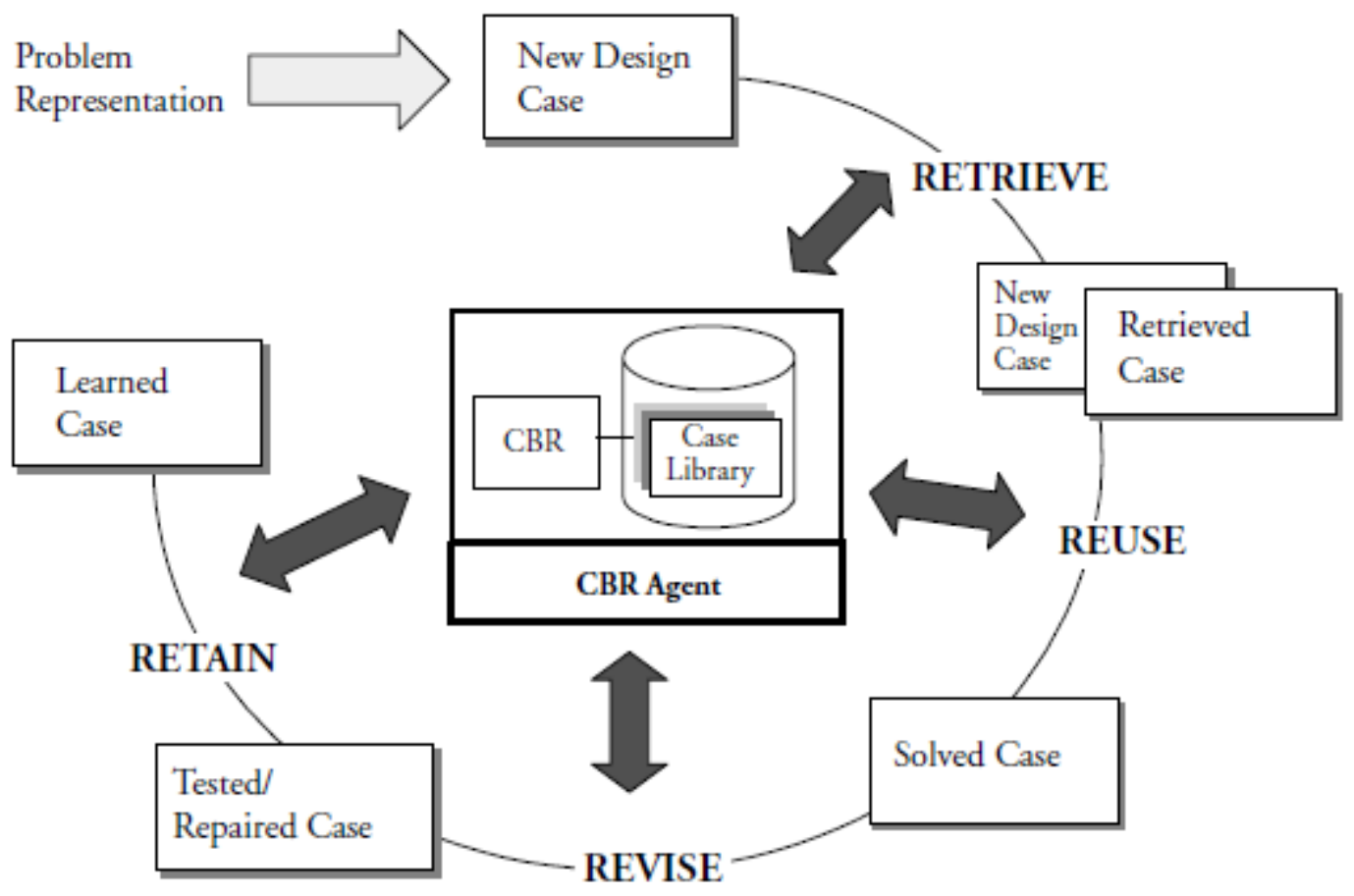

Gambar 2. Tahapan Metode Case-Based Reasoning

Dalam mencari pemecahan sebuah kasus baru, sistem Case-Based Reasoning akan mencari unsur yang paling banyak memiliki kemiripan (similar) dengan kasus lama di dalam basis kasus. Penyelesaian dari kasus lama dapat diadaptasikan secara lebih tepat dengan kebutuhan kasus baru. Inti dari aplikasi ini adalah melakukan proses similariti. Proses similariti menggunakan jaringan syaraf tiruan perceptron. Perceptron digunakan untuk mengklasifikasikan suatu tipe pola tertentu yang sering dikenal dengan pemisahan secara linier. Jaringan syaraf tiruan perceptron terdiri dari satu lapisan memiliki nilai bobot dan nilai ambang (threshold) yang dapat diatur. Fungsi aktivasi yang digunakan algoritma perceptron adalah fungsi hard limiting. Output unit akan diasumsikan bernilai 1 jika jumlah bobot inputnya lebih besar daripada threshold. Sedangkan nilai threshold pada fungsi aktivasi adalah non-negative. Similariti harus dapat diformulasikan melalui perhitungan similariti yang dimodelkan dengan mengkombinasikan beberapa parameter perhitungan similariti lokal untuk fitur individu dengan fungsi agregat global. Pengukuran similariti dapat dilakukan dengan perhitungan faktor pembobotan. Untuk melakukan perhitungan similariti dengan rumus pada nomor $1[11,12]$

$$
\text { Rumus Similarity }=\text { Similarity }(T, S)=\sum_{i=1}^{n} f(T i, S i) x p i
$$

\section{HASIL DAN PEMBAHASAN}

Pembuatan desain arsitektur aplikasi diagnosa kerusakan mesin sepeda motor matic melibatkan empat pengguna, yaitu admin, pakar, user dan Guest. Admin bertugas sebagai pengelola modul-modul dalam sistem, seperti melakukan update berita terbaru ke dalam database, agar informasi-informasi yang ada pada situs web selalu memiliki informasi terkini. Pakar bertugas menginputkan basis pengetahuan ke dalam basis data kasus. Basis pengetahuan yang diinputkan oleh pakar meliputi kasus-kasus terkait masalah kerusakan mesin dan solusi masalahnya. Selain itu, pakar juga bertugas melakukan evaluasi atau peninjauan ulang atas solusi yang disarankan kepada user (suggest solution) dalam menyelesaikan permasalahan yang dihadapi. Jika suggest solution tersebut sudah dapat mengatasi permasalahan yang dihadapi, 
solusi tersebut akan digunakan untuk menyelesaikan permasalahan pada kasus baru yang memiliki permasalahan serupa. Namun, bila suggest solution tersebut belum menyelesaikan masalah maka akan dilakukan revisi pada basis data kasus oleh pakar. Tahap ini dikenal dengan tahap Revise, jika terdapat kasus baru yang tidak cocok didalam basis data kasus, maka program akan menyimpan kasus baru tersebut didalam basis data pengetahuan dan menggunakan solusi baru sebagai bagian dari kasus baru, tahap ini dikenal dengan tahap Retain. Guest merupakan pengunjung yang belum menjadi anggota atau member. Guest hanya diperkenankan untuk mengakses berita/informasi dalam situs web. Guest tidak diperkenankan untuk mengakses fiturfitur tertentu seperti, fitur untuk melakukan diagnosa kerusakan mesin dan fitur forum diskusi untuk bertukar pikiran dan pengalaman penggunaan motor matic. Untuk mengakses fitur diagnosa dan forum, Guest harus melakukan register terlebih dahulu. Guest menjadi anggota atau member (user) dan dapat mengakses fitur-fitur dalam situs web setelah melakukan proses registrasi. User adalah pengguna aplikasi dengan cara melakukan input data atas masalah yang dihadapi terkait dengan kerusakan mesin pada motor matic. Data yang diinputkan oleh user akan diproses dan dihitung dengan metode similariti. Setelah diproses, aplikasi akan meretrieve data input tersebut yaitu melakukan proses pencarian sejumlah kasus-kasus yang terdapat dalam basis data kasus yang memiliki kemiripan dengan kasus baru yang diinputkan oleh user. Sistem akan menghitung nilai similaritas dalam setiap kasus, hasil similaritas tertinggi dalam kasus akan menjadi suggest solution, yaitu solusi yang akan disarankan kepada user dalam menyelesaikan permasalahan kerusakan motor matic. Tahap selanjutnya, solusi yang disarankan ke user (suggest solution) akan digunakan kembali (reuse) untuk kasus baru lainnya yang memiliki masalah serupa.

Pada tampilan awal sistem akan menampilkan halaman pengunjung, fitur yang dapat diakses user pada halaman ini dibatasi. Jika menu diagnosa atau menu forum di pilih maka sistem akan menampilkan peringatan agar user melakukan login terlebih dahulu untuk mengakses fitur secara penuh dan sistem akan menampilkan halaman login. User anggota yang lupa password dapat mengakses menu forget password, kemudian user diminta untuk mengisikan alamat email yang dimiliki user jika alamat email yang dimasukkan user valid, sistem akan mengirimkan password baru ke email user dan user dapat mengakses sistem dengan memasukkan password yang baru. Bagi user yang belum menjadi anggota dapat melakukan sign up pada halaman login, kemudian user akan diarahkan pada halaman sign up. Setelah user sukses melakukan sign up, halaman login akan ditampilkan kembali dan user melakukan login dengan mengisikan username dan password yang dimiliki.

Setelah sukses melakukan login sistem akan menampilkan halaman anggota, dimana pada halaman anggota user dapat mengakses semua fitur yang ada. User yang akan melakukan diagnosa dituntut untuk memberikan data masukkan berupa gejala yang dialami dan ciri-ciri kerusakan. Sistem akan melakukan perhitungan similarity sesuai dengan ciri-ciri yang dimasukkan user, kemudian sistem akan menampilkan halaman hasil diagnosa dan user dapat memilih kerusakan sesuai dengan nilai similaritas tertinggi, sistem akan menampilkan solusi penyelesaian sesuai dengan jenis kerusakan yang dipilih user. User yang memilih menu forum akan diarahkan pada halaman forum yang berisikan sejumlah topik-topik diskusi yang di posting oleh user yang lain. User dapat melakukan posting topik baru dengan memilih menu topik baru dan halaman untuk memasukkan topik akan ditampilkan kemudian user diminta untuk mengisikan nama, topik dan komentar. Setelah selesai mengisikan semua data topik akan ditampilkan pada halaman forum, user dapat memberikan komentar dengan memilih topik terlebih dahulu, sistem akan menampilkan isi topik dan user dapat menambahkan komentar dengan memilih menu komentar pada bagian atas halaman forum.

Peta situs pada sebuah situs web yang tertampil pada menu dan links adalah petunjuk bagi pengunjung terhadap halaman-halaman yang terdapat dalam web. Pengunjung akan semakin mudah menemukan halaman-halaman dalam situs web jika menu-menu dan links yang ada ditampilkan secara terstruktur. Peta situs web merupakan bagian dari situs web yang berguna untuk memandu pengunjung menjelajahi dan menelusuri isi seluruh situs web dan menghantarkan pengunjung pada isi situs yang menjadi kebutuhannya (Gambar 3). 
Citec Journal, Vol. 2, No. 3, Mei 2015 - Juli 2015

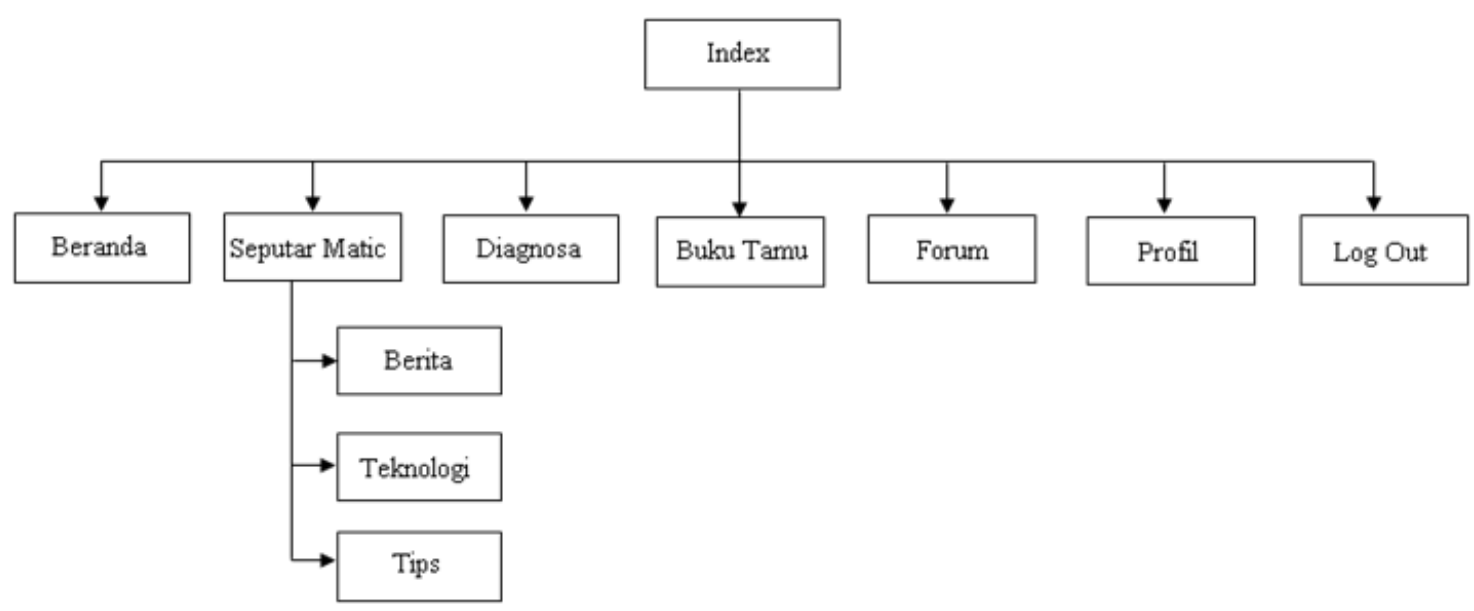

Gambar 3. Peta situs Web Diagnosa Kerusakan Mesin Sepeda Motor Matic

Untuk memodelkan aplikasi diagnosa kerusakan mesin sepeda motor matic menggunakan diagran state. Diagram ini memperlihatkan siklus hidup urutan keadaan sesaat (state) yang terjadi pada sebuah objek. Diagram state menggambarkan kejadian yang menyebabkan sebuah transisi dari satu aktivitas ke aktivitas yang lainnya dan aksi yang menyebabkan perubahan suatu aktivitas. Ketika pertama kali diakses sistem akan menampilkan halaman indeks, jika user melihat berita maka sistem akan menampilkan halaman berita yang terdiri dari beberapa kategori. Sistem akan menampilkan berita sesuai dengan kategori yang dipilih oleh user (Gambar 4).

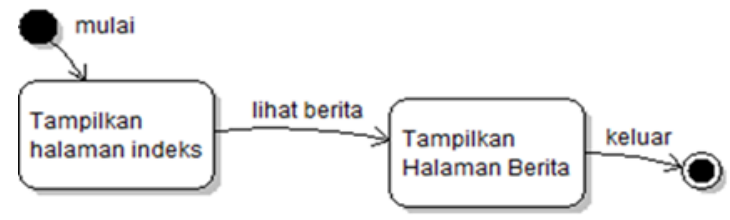

Gambar 4. Diagram State Halaman Berita

Saat user ingin mengisi buku tamu, sistem akan menampilkan halaman buku tamu yang digunakan untuk mengisi data pengunjung situs web serta detail jumlah tamu yang mengisi kunjungan buku tamu pada situs web (Gambar 5).

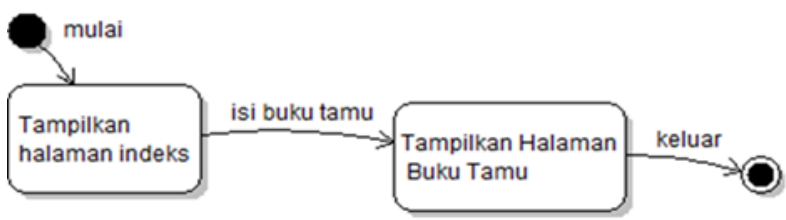

Gambar 5. Diagram State Halaman Buku Tamu

Saat pengunjung akan mengakses menu diagnosa, sistem akan mengarahkan pengunjung ke halaman login terlebih dahulu sebelum menggunakan fitur diagnosa. Pada halaman login, pengunjung yang belum terdaftar sebagai anggota situs web akan diarahkan ke halaman register untuk mendaftarkan diri sebagai anggota dapat mengoptimalkan proses validasi untuk semua kompenen pembuatan sistem (Gambar 6). 


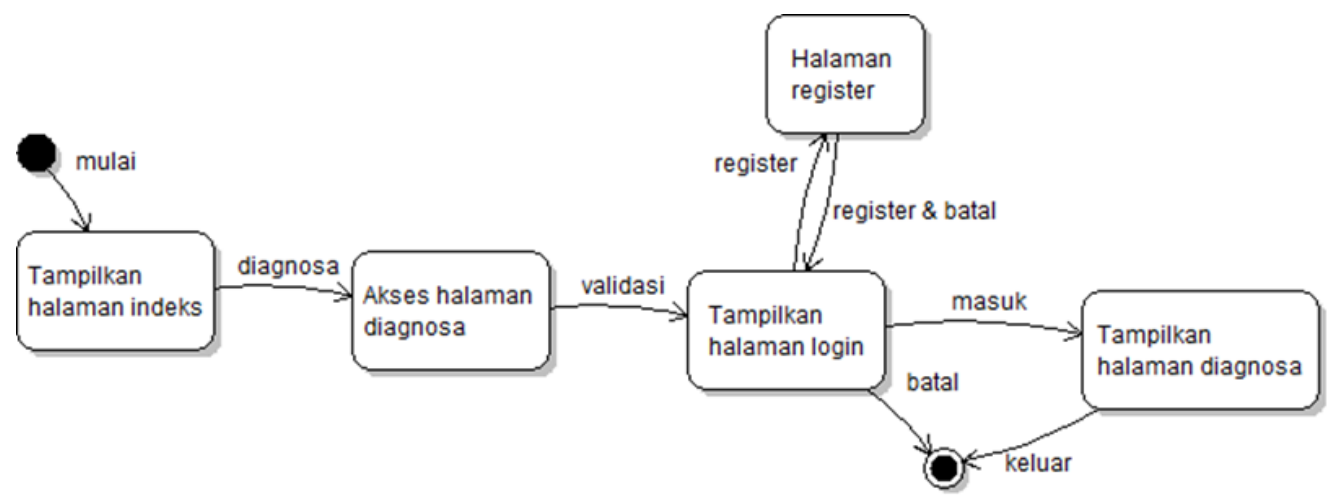

Gambar 6. Diagram State Halaman Diagnosa

Ketika pengunjung akan mengakses menu forum diskusi, sistem akan mengarahkan pengunjung ke halaman login terlebih dahulu sebelum menggunakan fitur forum diskusi. Pada halaman login, pengunjung yang belum terdaftar sebagai anggota akan diarahkan ke halaman register untuk mendaftarkan diri sebagai anggota. Pengunjung yang sudah terdaftar sebagai anggota dapat mengguanakan fitur forum diskusi dengan mengisikan username dan password yang dimilikinya. Apabila data yang diinputkan user sesuai dengan database sistem, maka akan ditampilkan halaman forum dan pengunjung dapat menggunakan fitur forum diskusi. Setelah pengunjung selesai melakukan tukar pendapat di forum diskusi, pengunjung yang akan meninggalkan situs web ini diharapkan logout terlebih dahulu untuk menjaga keamanan identitas pengunjung sebagai anggota. Untuk mencegah user yang keluar dari situs web tanpa melakukan loguot terlebih dahulu, maka sistem akan segera melakukan logout dengan sendirinya apabila user tidak mengakses situs web dalam jangka waktu 90 detik. Hal ini bertujuan untuk menjaga keamanan identitas pengunjung situs web yang lupa melakukan logout (Gambar 7).

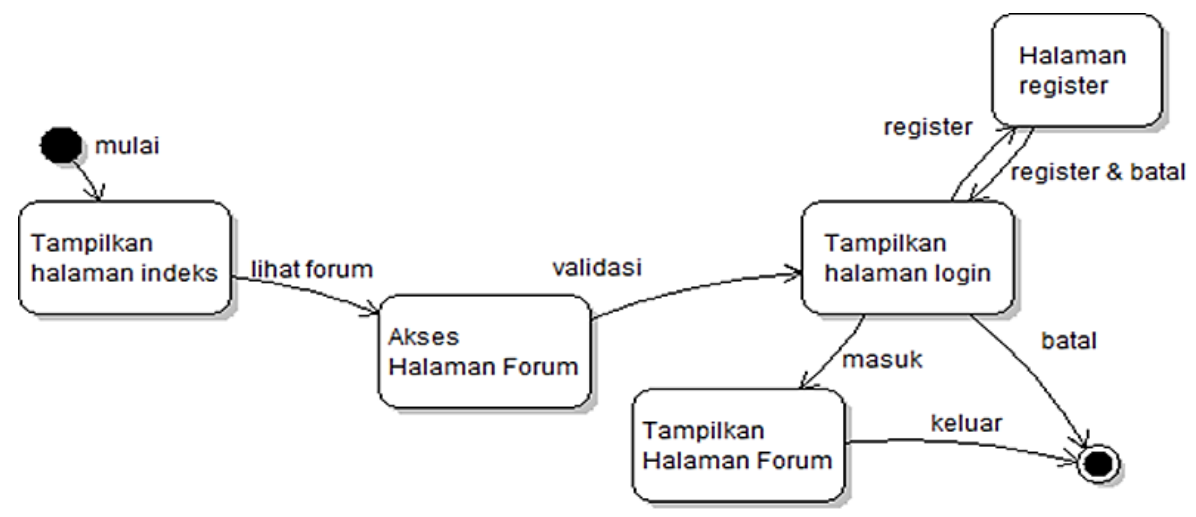

Gambar 7. Diagram State Halaman Forum

Untuk memodelkan perilaku sistem diagnosa kerusakan mesin sepeda motor matic menggunakan diagram sequence. Diagram sequence dapat memperlihatkan sejumlah objek dan pesan yang ada diantara objek-objek di dalam sebuah sistem. Saat user memilih halaman login, maka pada halaman ini user yang sudah menjadi anggota dapat langsung mengakses halaman anggota dengan memasukkan username dan password, untuk user yang belum terdaftar dapat bergabung dengan melakukan sign up terlebih dahulu, sedangkan untuk user anggota yang lupa password dapat mengakses halaman lupa password dan password akan dikirimkan kepada user melalui account e-mail masing-masing user (Gambar 8). 
Citec Journal, Vol. 2, No. 3, Mei 2015 - Juli 2015

ISSN: 2354-5771

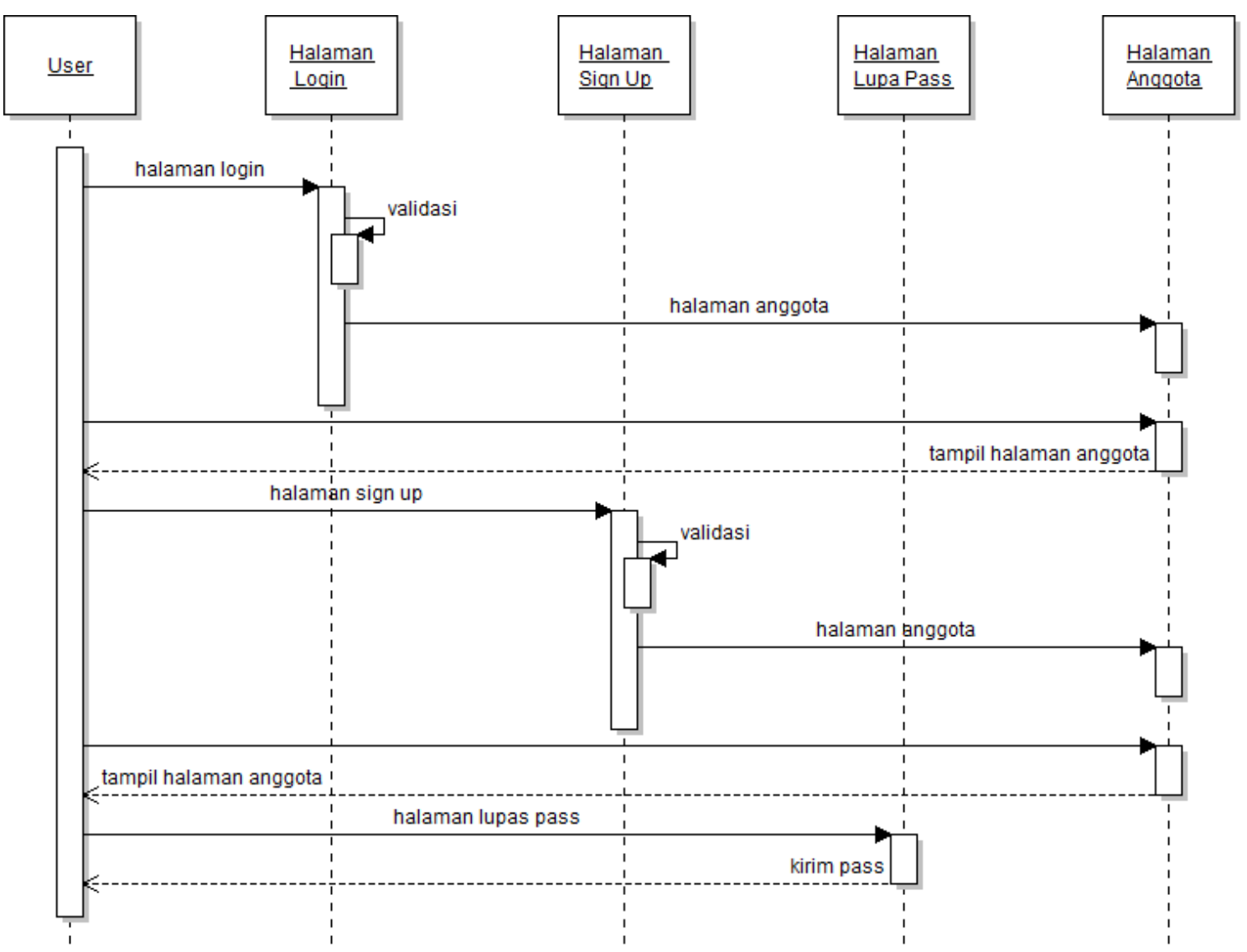

Gambar 8. Diagram Sequence Registrasi User

Selanjutnya user dapat melakukan pencarian berita atau informasi pada halaman utama berdasarkan kata kunci atau kebutuhan pencarian sesuai kebutuhan user. Hasil pencarian akan ditampilkan dan user dapat melihat secara terperinci segala aspek yang berkaitan dengan diagnosa kerusakan mesin sepeda motor matic (Gambar 9).

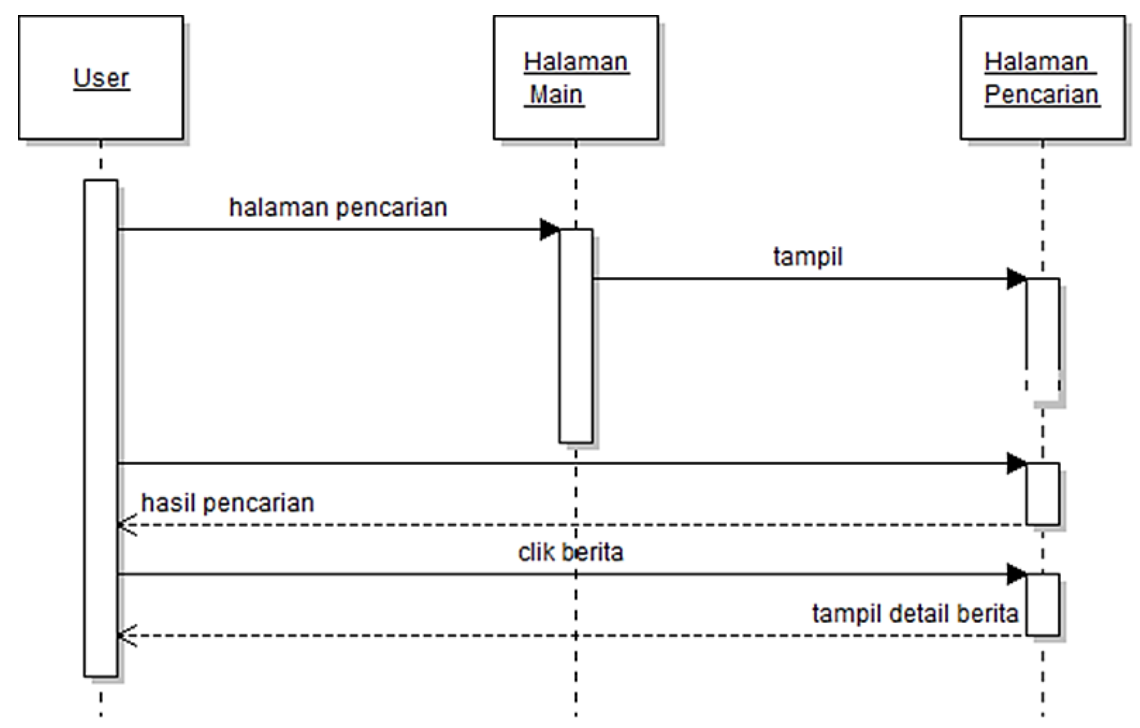

Gambar 9. Diagram Sequence Pencarian Berita 
Dalam melakukan kegiatan mendiagnosa kerusakan mesin sepeda motor motor matic, user dapat memasukkan gejala-gejala yang dialami kemudian sistem akan mendiagnosa dan mencocokkan gejala-gejala yang dimasukkan kemudian mengecek apakah gejala yang dimasukkan sudah pernah terjadi, kemudian sistem akan menghitung similaritas kecocokan gejala dan menampilkan solusi mengenai jenis kerusakan dan solusinya (Gambar 10).

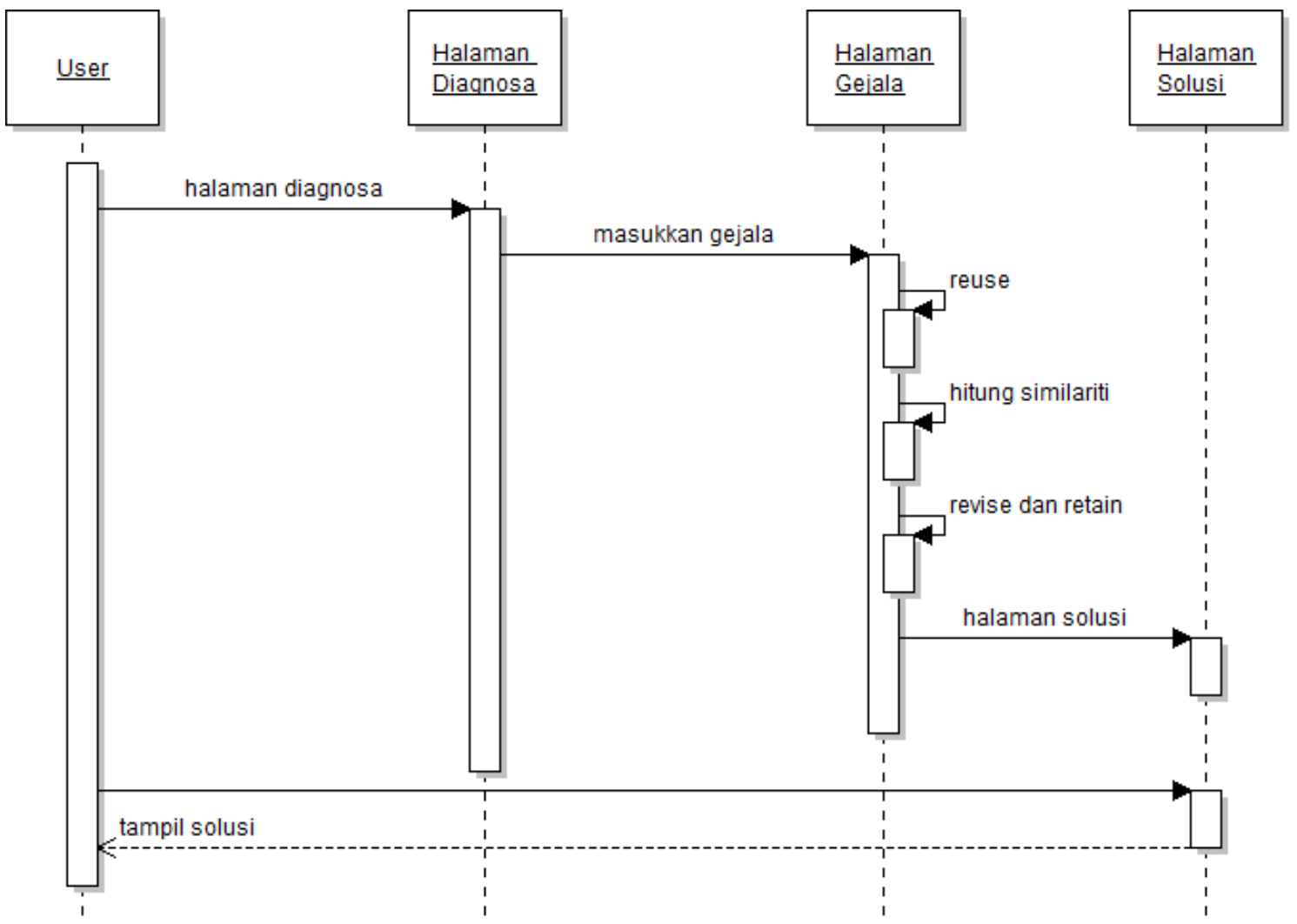

Gambar 10. Diagram Sequence Diagnosa Kerusakan Mesin

Perhitungan similaritas merupakan faktor penting, karena kemiripan sebuah kasus harus baru harus dapat memperlihatkan tingkat kemiripannya dengan kasus lama. Ketidaksesuaian dengan kasus sebelumnya harus menjadi sebuah kasus baru untuk basis data kasus yang sudah ada. Perhitungan similaritas merupakan modul perhitungan nilai dengan membandingkan data kasus lama dengan data kasus baru yang diinputkan oleh user. Sistem akan mencocokkan kasus lama yang terdapat dalam basis data kasus yang memiliki masalah serupa dengan kasus baru, kemudian melakukan proses perhitungan similaritas dengan membandingkan data input user dengan data yang terdapat dalam basis data kasus. Pengujian ini untuk mengetahui apakah sistem dapat atau tidak dapat menghitung nilai similaritas dengan tepat (Gambar 11). 
Citec Journal, Vol. 2, No. 3, Mei 2015 - Juli 2015

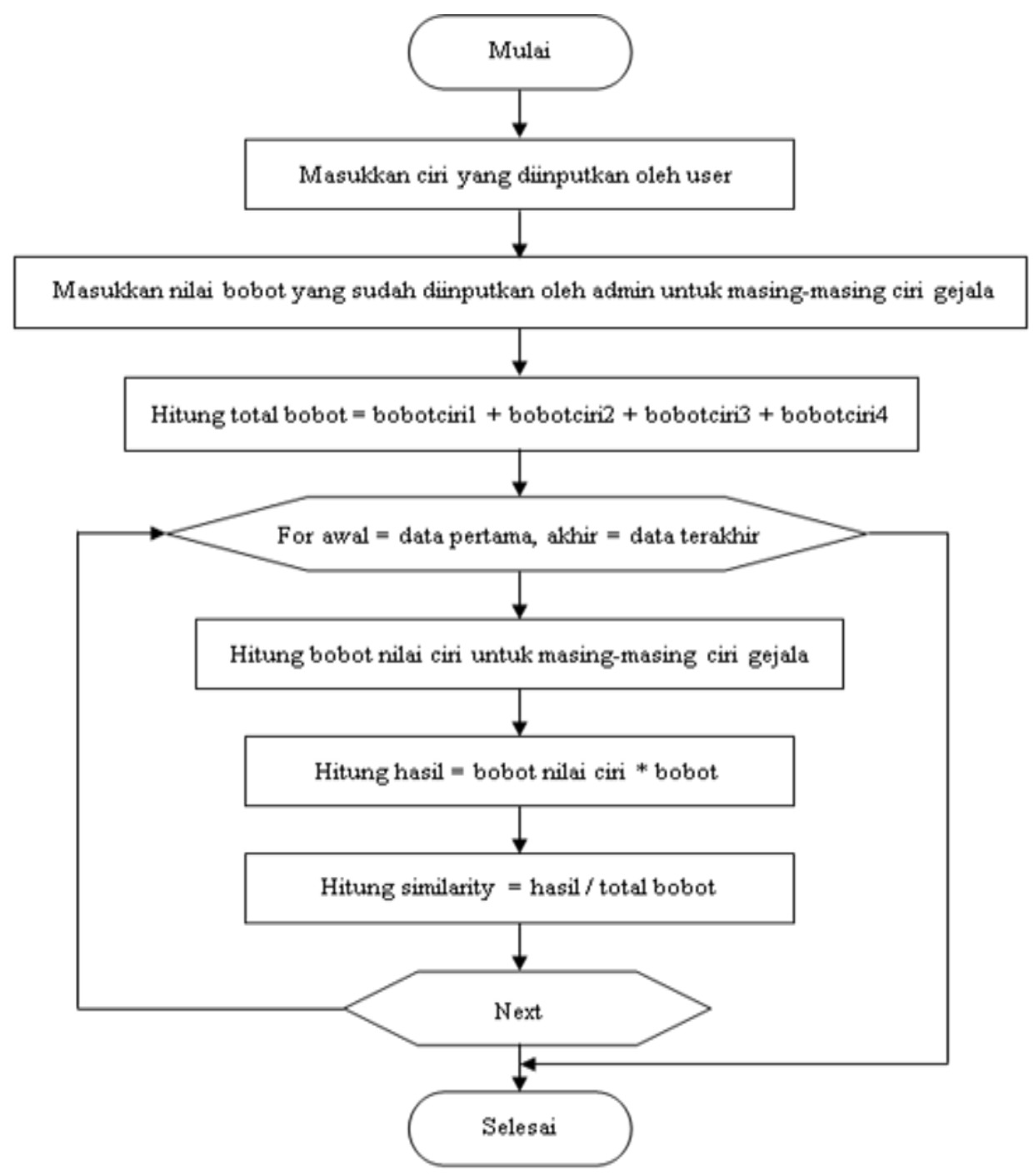

Gambar 11. Bagan Alir Perhitungan Similaritas

Basis data merupakan bagian penting dalam aplikasi ini. Semua ciri, gejala dan solusi harus memiliki tempat penyimpanan secara baik dan memiliki relasi yang tepat pada saat proses update basis data kasus sebagai pengetahuan dalam proses pembuatan keputusan. Semua tabel data harus memiliki relasi yang tepat sesuai kebutuhan pengolahan datanya. Hal ini penting mengingat semua proses saling berhubungan. Untuk menampilkan semua relasi ini menggunakan diagram hubungan entitas (Gambar 12). 


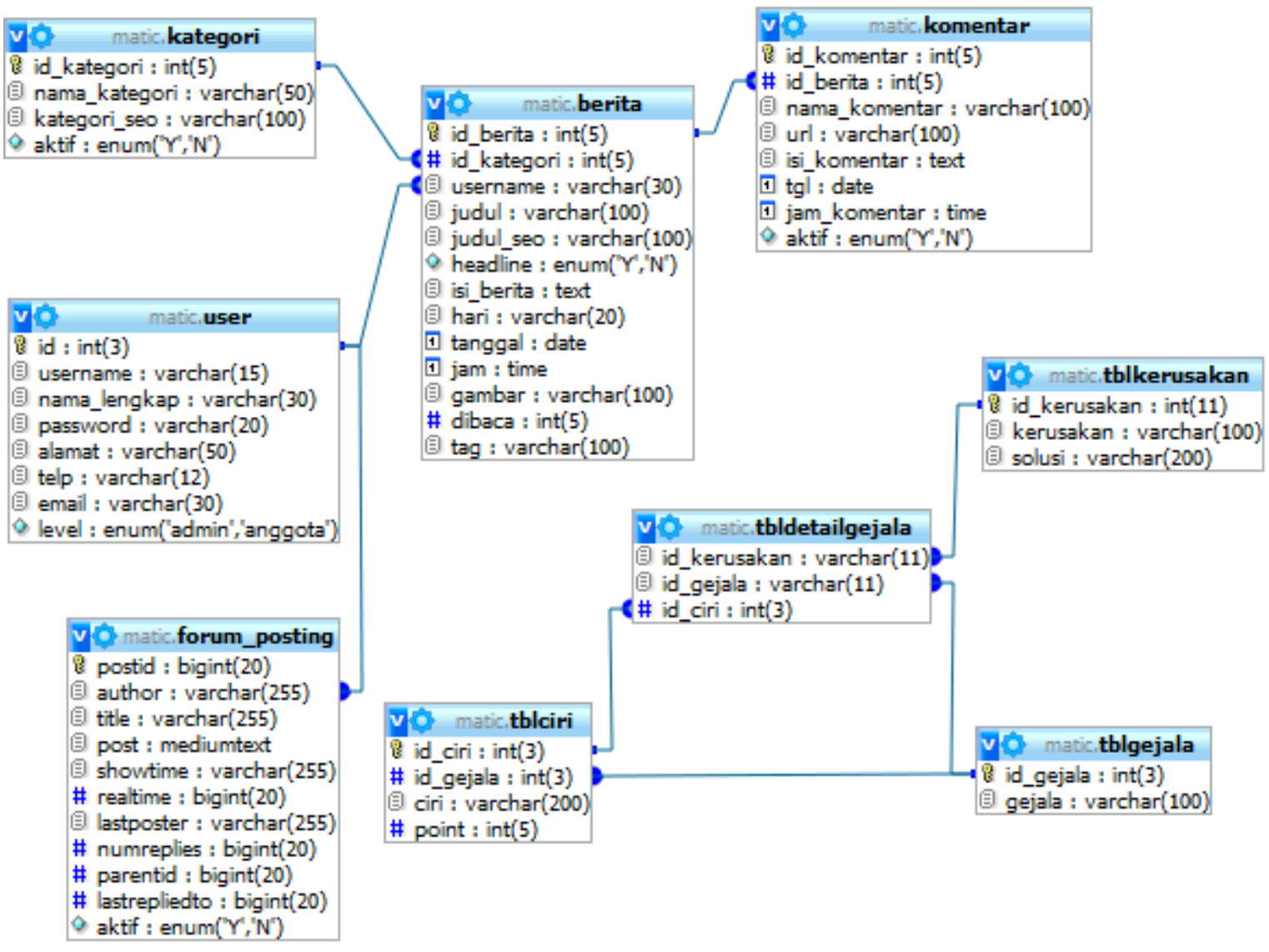

Gambar 12. Diagram Hubungan Entitas

Pembuat aplikasi diagnosa kerusakan mesin sepeda motor matic menggunakan bahasa pemrograman PHP. Program aplikasi ini memiliki 3 halaman utama yang meliputi halaman pengunjung, halaman anggota, dan halaman admin. Halaman pengunjung diperuntukkan bagi user yang belum terdaftar sebagai anggota dimana user memiliki keterbatasan dalam mengakses fitur yang disediakan pada situs web, halaman anggota diperuntukkan bagi user yang sudah terdaftar sebagai anggota dan pada halaman ini user dapat mengakses semua fitur yang ada. Halaman admin digunakan admin untuk mengelola situs web dan mengupdate database. Aplikasi ini juga memiliki sejumlah fitur penting, selain memberikan berbagai informasi edukasi bagi pengguna sepeda motor matic juga sistem memiliki tips perawatan kendaraan matic. Berikut ini merupakan sejumlah desain tampilan proses diagnosa kerusakan mesin motor matic (Gambar 13 s/d 18). 
Citec Journal, Vol. 2, No. 3, Mei 2015 - Juli 2015
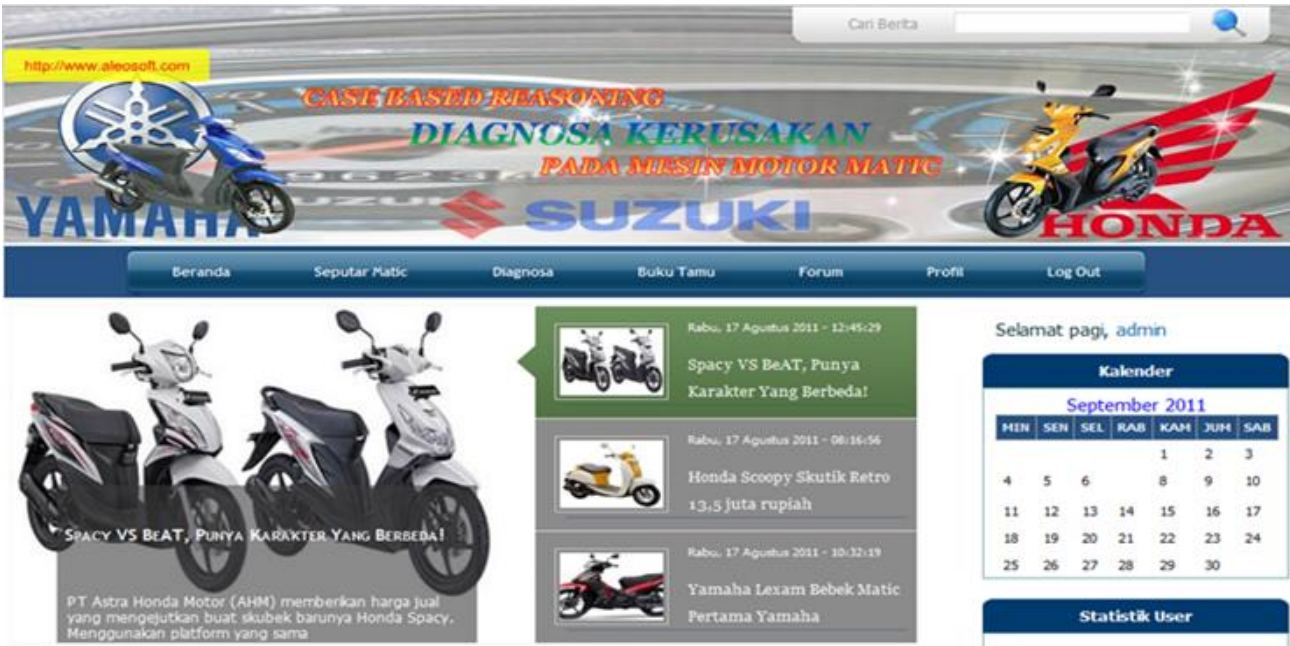

Selamat pagi, admin

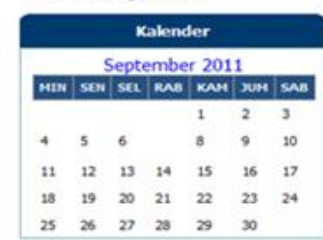

Gambar 13. Halaman Beranda Utama

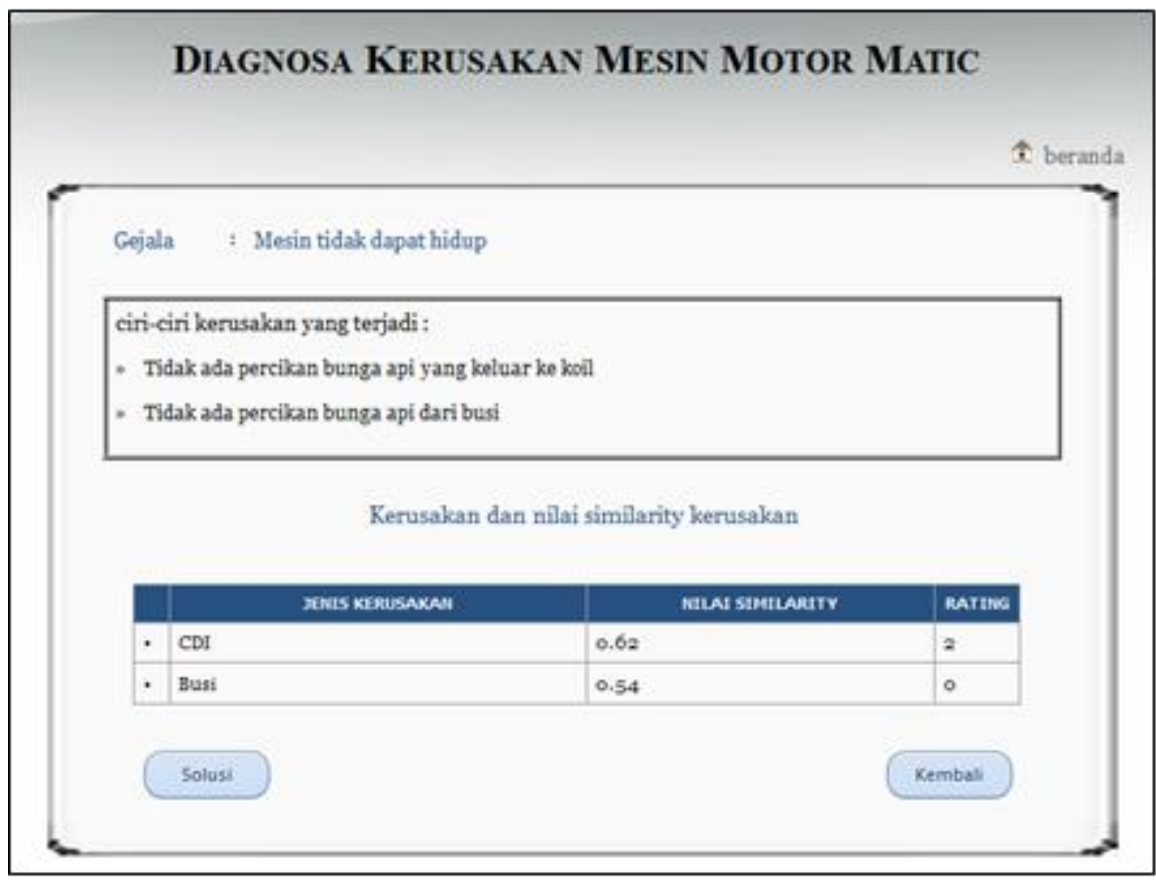

Gambar 14. Memasukan Informasi Gejala Kerusakan 


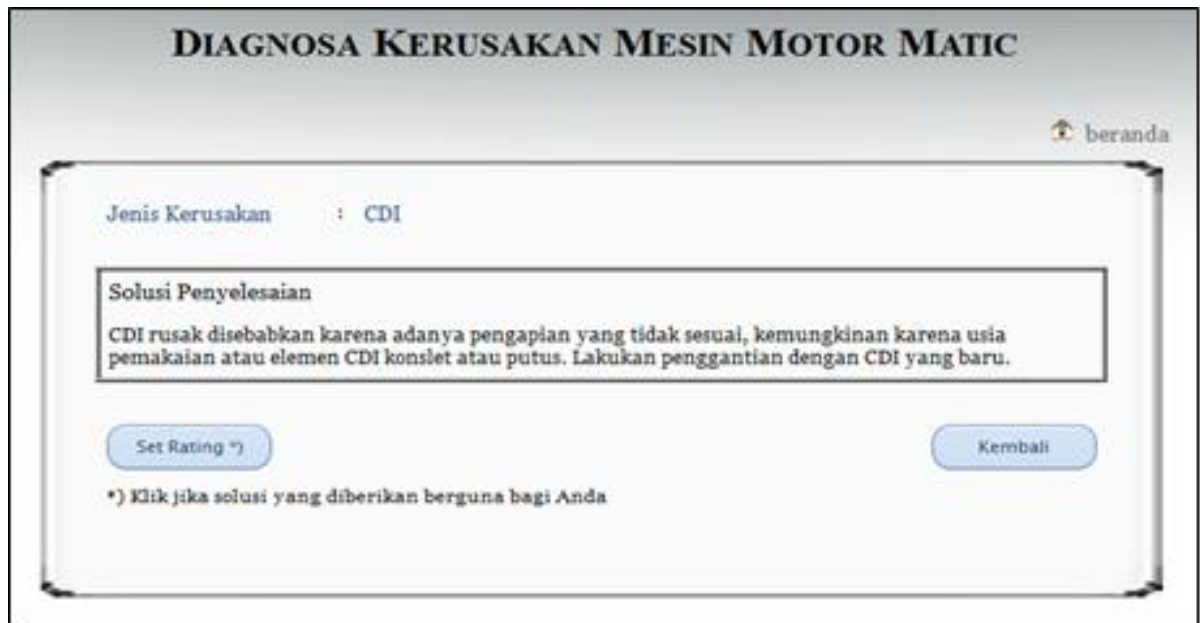

Gambar 15. Menampilkan Jenis Kerusakan dan Solusi Penyelesaian

\begin{tabular}{|c|c|c|c|c|c|c|}
\hline \multicolumn{7}{|c|}{ Basis Pengetahuan } \\
\hline \multirow[b]{2}{*}{ no } & \multicolumn{2}{|c|}{ Histori } & Data Kerusakan & \multirow{2}{*}{$\begin{array}{c}\text { Data Gejala } \\
\text { ciks }\end{array}$} & \multicolumn{2}{|c|}{ New Case } \\
\hline & eERin & GonIA & to cira & & stousakam & 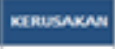 \\
\hline 1 & Gxo001 & Mesin bodk depost hidep & cro00021 & Tidak ada percken bunga aci dan bus: & KE:50006 & Starter Assy \\
\hline 2 & Gxo00: & Meun sdak dopot hides & CRo0015 & 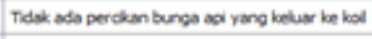 & Nospo006 & Startes Asty \\
\hline 3 & Gxo00: & Mesin sdak depot hidep & CRoO0023 & Tidek ado perden burga nol deri starter asty & NES0006 & Starte Assy \\
\hline 4 & Gxo001 & Mesin bold depost hidep & 0200015 & Tidek ada perciban bunga aci dian kal & Nes0006 & Starter Assy \\
\hline 5 & Gxo00: & Mesin sodok depot hidep & Cro00021 & Tdek ade percken burges asi deri bus: & NRS00007 & $\cos$ \\
\hline 6 & Gxo00: & Mesin sdok depot hidep & crooo:s & 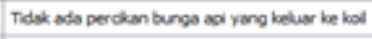 & kespo007 & $\cos$ \\
\hline 7 & Gxo001 & Mesin bolk depot hides & c2000016 & Tidak ada perclean burga asi don kal & N2500007 & $\cos$ \\
\hline 8 & Gxo00: & Mesin sodek desost hidep & CRo0021 & Tidak ada percken burga adi dari bus & KRso000 & Koll \\
\hline 9 & Gxo00: & Mesin sodok depost hides & CR000:s & Tidek ado percken bunga as dan kol & NESO0000 & Koll \\
\hline 10 & Gxo001 & Mesin bolk dopot hide & Croo021 & Tidek ado periken burga asi den bus: & nesoon 12 & an: \\
\hline
\end{tabular}

Gambar 16. Menampilkan Basis Pengetahuan

\begin{tabular}{|c|c|c|c|c|c|c|c|}
\hline \multicolumn{8}{|c|}{ Histori } \\
\hline мо & ID GEALA & GEALA & ID CIRI & CIRI & $\begin{array}{c}\text { ID } \\
\text { KERUSAKAM }\end{array}$ & KERUSAKAN & AKSI \\
\hline 1 & GJL0004 & Tarkan motor berkurang & CR00004 & Kecepatan motor berkurang & KRS0003 & Wap & $x$ \\
\hline 2 & GJ0001 & Mesin tdak dapat hidup & CR00021 & $\begin{array}{l}\text { Tidak ada perokan bunga } \\
\text { api dari busi }\end{array}$ & KRS0008 & Koil & $x$ \\
\hline 3 & GJL0004 & Tarkan motor berkurang & CR00005 & $\begin{array}{l}\text { Motor tidak dapat berjalan } \\
\text { saat di gas }\end{array}$ & KRS0002 & V-balt & $x$ \\
\hline 4 & GJL0005 & $\begin{array}{l}\text { Suara mendengung pada } \\
\text { CVT }\end{array}$ & CR00010 & $\begin{array}{l}\text { Suara kasar pada bagian } \\
\text { belakang mesin }\end{array}$ & KRS0001 & Secondari & $x$ \\
\hline 5 & GJL0006 & $\begin{array}{l}\text { Mesin motor sering mat } \\
\text { mendadak sat menempuh } \\
\text { jarak kurang lebih } 1 \mathrm{KM}\end{array}$ & CR00024 & Mesin tersendat-sendat & KRS0005 & Karburator & $x$ \\
\hline \multicolumn{8}{|c|}{ (14) (1) (1) (1) } \\
\hline \multicolumn{8}{|c|}{ Kembali } \\
\hline
\end{tabular}

Gambar 17. Menampilkan Data Histori 


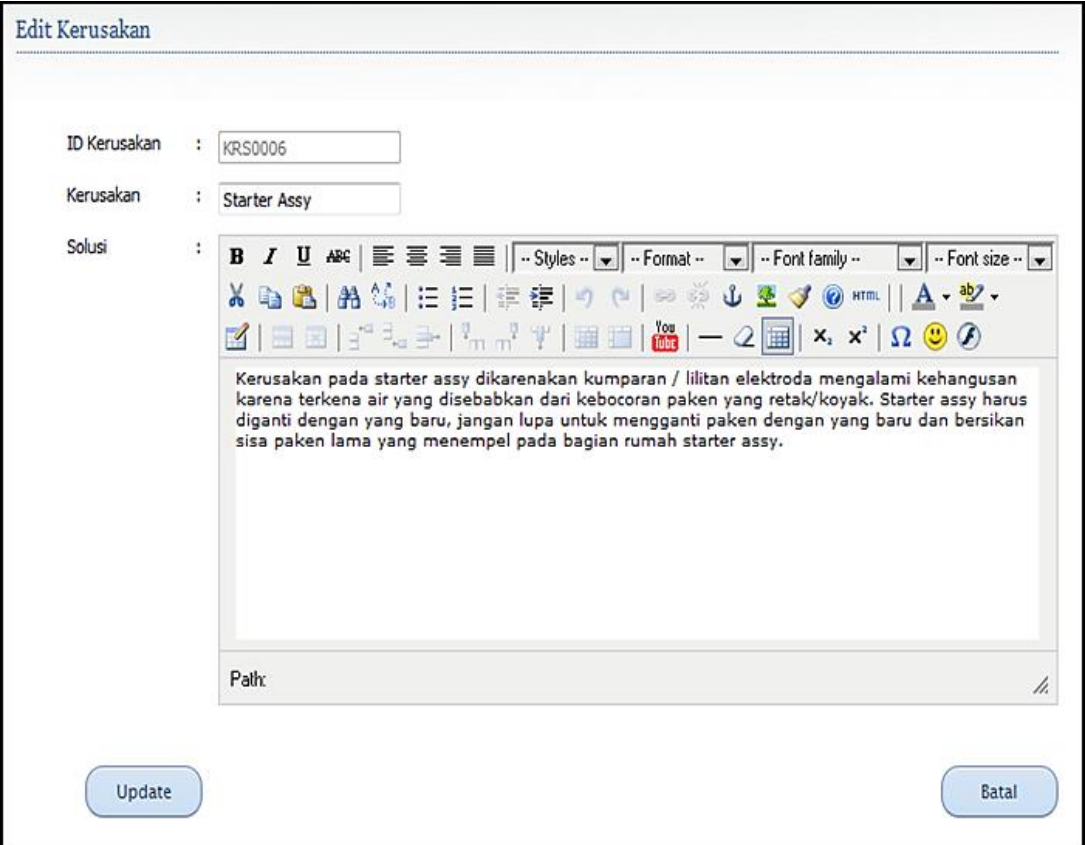

Gambar 18. Menambah dan Mengedit Data Kerusakan

Pengujian aplikasi meliputi proses login dan keakuratan nilai similaritas. User harus menginputkan username dan password melalui proses validasi. Jika username atau password yang diinputkan salah, sistem akan menampilkan pesan kesalahan login. User dapat mengulangi login kembali dengan memasukkan username dan password, jika username dan password yang diinputkan benar maka sistem akan menampilkan halaman anggota. Pengujian ini untuk mengetahui keakuratan nilai similaritas suatu kasus dibandingkan dengan analisis pakar. Untuk pengujian pertama, hasil pengujian perbandingan keakuratan sistem dengan pakar dapat disimpulkan bahwa sistem yang dirancang mampu untuk mendiagnosa kerusakan dan memberikan solusi penyelesaian masalah yang dialami oleh user dengan nilai similaritas 0,62 dan keakuratan solusi yang diberikan oleh pakar sebesar $80 \%$. Untuk pengujian yang kedua, hasil pengujian perbandingan keakuratan sistem dengan pakar dapat disimpulkan bahwa sistem yang dirancang mampu untuk mendiagnosa kerusakan dan memberikan solusi penyelesaian masalah yang dialami oleh user dengan nilai similaritas 0,7 dan keakuratan solusi yang diberikan oleh pakar sebesar $90 \%$.

\section{KESIMPULAN}

Melalui pembuatan aplikasi diagnosa kerusakan mesin sepeda motor matic berbasis web dapat memberikan informasi dan solusi penyelesaian terhadap kerusakan yang dialami oleh pengguna. Setiap hasil solusi yang diberikan sistem kepada user dapat diberikan rating yang menandakan seringnya kerusakan yang terjadi dan solusi yang diberikan aplikasi tersebut menjadi penyelesaian, dimana rating ini akan menjadi bahan pertimbangan bagi admin dalam melakukan perbaikan dan memberikan pengembangan pada database. Pengguna sepeda motor matic dapat menambah edukasi mengenai informasi seputar perawatan dan pemeliharaannya dalam memperpanjang umur kendaraan tanpa batasan waktu dan tempat. Hasil aplikasi ini sementara hanya dapat menangani komponen-komponen kerusakan mesin seperti starter assy, CDI, koil, karburator, secondary, V-balt, WAP, gigi reduksi, dan valve. 


\section{SARAN}

Menambahkan komponen-komponen kerusakan dan diagnosisnya secara lebih lengkap agar aplikasi diagnosa kerusakan mesin sepeda motor matic dapat bekerja lebih menyeluruh dan memiliki antarmuka yang lebih bersifat interaktif. Sistem dapat menjadi lebih dinamis terutama dalam konten yang memiliki unsur-unsur visualiasi dan pengguna dapat melakukan komunikasi secara langsung dengan admin untuk kasus-kasus yang kemiripannya sangat spesifik.

\section{DAFTAR PUSTAKA}

[1] Russell, S., Norvig, P., 2014, Artificial Intelligence a Modern Appoach, 3rd Edition, Pearson Education Limited, Edinburgh Gate Harlow.

[2] Aryani, Adriana, S., Indarto, A., 2008, Penalaran Komputer Berbasis Kasus (Case Based Reasoning - CBR), Edisi Kesatu, Ardana Media, Yogyakarta.

[3] Pal, S. K., Shiu, S. C. K., 2004, Foundation of Soft Case-Based Reasoning, John Willey and Sons, Inc., Hoboken, New Jersey.

[4] Aribowo, Agus, S., Khomsah, S., 2012, Metode Case Retrieve Dalam Case Based Reasoning Untuk Identifikasi Penyakit Manusia, Prosiding: Seminar Nasional Informatika 2012 (SNIf 2014), STMIK Potensi Utama, Medan, 19 Oktober 2012.

[5] Aribowo, Agus S., 2010, Pengembangan Sistem Cerdas Menggunakan Penalaran Berbasis Kasus (Case-Based Reasoning) Untuk Diagnosa Penyakit Akibat Virus Eksantema, Telematika, No. 1, Vol.7, Juli 2010, hal 11-22.

[6] Aribowo, Sasmito, A., Khomsah, S., 2012, Penalaran Berbasis Kasus Untuk Deteksi Dini Penyakit Leukemia, Seminar Nasional Informatika 2012 (semnasIF 2012), UPN "Veteran" Yogyakarta, 30 Juni 2012.

[7] Kosasi, S., 2014, Penerapan Case-Based Reasoning Untuk Mendiagnosis Penyakit Diare Pada Manusia, Prosiding: Seminar Nasional Sains dan Teknologi Informasi (SeNASTi), ISSN: 2355-536X, STMIK Kharisma, Makassar, 12 Mei 2014.

[8] Wihayanti, T., Gumilang, S. F. S., 2014, Penerapan Metode Case Based Reasoning Dan Forward Chaining Pada Sistem Pakar Untuk Diagnosa Awal Penyakit Ginjal, Prosiding: Konferensi Nasional Sistem Informasi 2014, STMIK Dipanegara Makassar 27 Pebruari - 1 Maret 2014.

[9] Nugraheni, M., 2012, Rancangan Case-Based Reasoning Menggunakan Sorenson Coefficient, Jurnal Informatika, No.1, Vol.6, hal 612-616.

[10] Sommerville I., 2010, Software Engineering (Ninth ed.), Addison-Wesley.

[11] Powell, J., 2011, A Generic Web-Based Knowledge Discovery Framework for Case-Based Reasoning, Dissertation, Doctor of Philosophy in the Department of Computer Science, Indiana University, United States.

[12] Cook, C., 2011, A Web-Integrated Environment For Component-Based Software Reasoning, Thesis, Master of Computer Science, Presented to the Graduate School of Clemson University, United States. 